\title{
A COMPARATIVE STUDY ON FORCE BASED DESIGN AND DIRECT DISPLACEMENT BASED DESIGN OF REINFORCED CONCRETE
}

\author{
FRAMES
}

\author{
Vivinkumar.R.V. ${ }^{1}$, Karthiga.S ${ }^{2}$ \\ ${ }^{1} P G$ Student, Department of civil engineering, SRM University, Kancheepuram, Tamilnadu, India \\ ${ }^{2}$ Assistant Professor, Department of civil Engineering, SRM University, Kancheepuram, Tamilnadu, India
}

\begin{abstract}
In recent times, many research works related to seismic resistant design of structures were done and various methods of seismic resistant design were predicted and this study explains about two major seismic design methods (i.e) Force Based Design(FBD) and Direct Displacement Based Design(DDBD) in which former is a conventional method while later one is a performance approach of design. Design and Analysis were done on two dimensional bare frames of four, eight and twelve stories based on following codes IS 456, IS 1893:2000, FEMA 356 and the two design approaches were studied. Analysis and design for this study was done using Structural Analysis Program software(SAP 2000). Both design approaches is validated using non linear time history analysis for 16 different ground motion of PGA $=0.32 \mathrm{~g}$. Structural parameters like Drift Ratio, Ductility Demand and Base shear were compared within the frames of different stories and between design approaches.
\end{abstract}

Keywords: Force Based Design (FBD), Direct Displacement Based Design (DDBD), Base Shear, Ductility, Inter storey Drift, Reinforced Concrete Frames, FEMA.

\section{INTRODUCTION}

The major cause for building damage is due to seismic effect. As the ground shakes, building loses its stability and gets collapsed. So for any structure, seismic analysis is mandatory as it resists the structure against the seismic forces. In different parts of world, different methods of seismic analysis are practiced. we consider two different seismic approaches for our study:

i. Force Based Design Method (FBD).

ii. Direct Displacement Based Design Method (DDBD)

\subsection{Force Based Design}

Force based design method practised in India, which focus on the seismic force over the structure. In this method, the design procedure is carried out for the seismic force acting on the system where stiffness, time period and strength are the initial properties of the design. FBD method is performed based on IS1893(Part 1):2002. The existing conventional code based procedures are normative in nature ${ }^{[2]}$. This code needs to cover a wide range of structures and this method usually cannot be considered as the expected performance level and seismic risk levels are not generalized. Linear elastic analysis of the structure is performed for the lateral forces calculated from the procedure.

\subsection{Performance Based Design}

The process of designing the structure for seismic resistance has been undergoing a critical reappraisal in recent years, with the emphasis changing from strength to performance ${ }^{[10]}$. This lead to an approach towards a new design concept called "Performance-Based Seismic Design (PBSD)".
The Structural Engineers Association of California (SEAOC) in their Vision 2000 document defines the performance objective for the buildings and gives certain expected performance level for ground motions at a specific site to define the acceptability criteria for the structure. Performance objectives are 'Life Safety(LS), Collapse Prevention(CP), Operational Level(O)', in which LS was the major focus to reduce the threats to the life safety of the structure ${ }^{[3]}$.

FEMA 356-2000 code was referred for PBD and based on the above code values, the displacement profile can be chosen along with the initial displacement value ${ }^{[7]}$.

\subsection{Direct Displacement Based Design}

Direct Displacement-Based Design (DDBD), first proposed by Priestley (1993) is a performance design approach in which Performance levels, indeed, are described in terms of displacements, as damage is better correlated to displacements rather than forces ${ }^{[5]}$. The fundamental goal of DDBD is to obtain a structure which will reach a target displacement profile when subjected to earthquakes consistent with a given reference response spectrum. The performance levels of the structure are governed through the selection of suitable values of the maximum displacement $\left(D_{d}\right)$ and maximum interstorey $\operatorname{drift}\left(\theta_{d}\right)$.

In our study, we follow Nonlinear dynamic seismic analysis procedure. The Nonlinear dynamic analysis procedure utilizes a combination of ground motion records with a detailed structural model, and therefore is capable of producing results with relatively low uncertainty ${ }^{[6]}$. The detailed structural model subjected to a ground motion record 
produces estimates of component deformations for each degree of freedom in the model and the model responses are combined using schemes such as square-root-sum of squares. The method captures the effect of amplification due to resonance, the variation of displacements at diverse levels of a frame, an increase of motion duration, and a tendency of regularization of movements.

\section{MODELLING}

Accurate modelling of the nonlinear properties of various structural elements is very important in nonlinear analysis of any structure and since the present study is based on the nonlinear analysis of structural models of regular multistoried buildings. In the present study the structural models of the 2-D frames used are modelled, designed and analysed using the finite element software Structural Analysis Program SAP-2000 version 14. The analytical software SAP(Structural Analysis Program) is a computational tool for modelling and analysing structures. The $2 \mathrm{D}$ model is analysed on two different seismic approach. The modelling of the frames involves assemblage of various structural and non-structural elements. It also includes defining material properties, sectional properties, load cases and non-linear hinge properties. The frame was designed for zone III with $\mathrm{PGA}=0.16 \mathrm{~g}$ and structural parameters for 16 different ground motions are obtained.

\subsection{Building Geomentry}

Regular 2-D frames with storey height $3 \mathrm{~m}$ and bay width $6 \mathrm{~m}$ are considered. Frames with four, eight and twelve stories are studied. The design of all the frames was according to the Indian standards IS 456(2000), seismic code IS 1893(2002) and ductile detailing code IS 13920:1993.

The two dimensional $4,8 \& 12$ storey frames were modelled by assigning the beam and column dimensions. A series of iteration was carried out for the structure to get apt section. Below table 1 shows the dimensions of beams for $4,8 \& 12$ stories.

Table 1 Dimensions of beams

\begin{tabular}{|l|l|}
\hline No of storey & Dimensions of Beams(mm) \\
\hline 4 & $450 * 230$ \\
\hline 8 & $450 * 230$ \\
\hline 12 & $450 * 230$ \\
\hline
\end{tabular}

Below table 2 shows the dimensions of columns for $4,8 \&$ 12 stories.

Table 2 Dimensions of columns

\begin{tabular}{|l|l|}
\hline No of storey & Dimensions of Columns (mm) \\
\hline 4 & $300 * 300$ \\
\hline 8 & $400 * 300(1-4$ storey) \\
$300 * 300(5-8$ storey) \\
\hline \multirow{2}{*}{12} & $\begin{array}{l}500 * 300 \text { (1-6 storey) } \\
400 * 300 \text { (7-12 storey) }\end{array}$ \\
\hline
\end{tabular}

The material property for all the members in frames as follows

Young Modulus of concrete : $22360000 \mathrm{~N} / \mathrm{mm}^{2}$

Poisson's Ratio $(\mu)$ of concrete : 0.15

Maximum yield stress : $415 \mathrm{~N} / \mathrm{mm}^{2}$

Grade of concrete : $25 \mathrm{~N} / \mathrm{mm}^{2}$

Modulus of elasticity of rebar : $1.999 \mathrm{E}+08$

Poisson's Ratio $(\mu)$ of rebar : 0.3

All the load values as shown in table 3 are taken from IS 875$1 \&$ 2, IS 1893-2002(Part-1) codes.

Table 3 Load values for the frames

\begin{tabular}{|l|l|}
\hline Types of loads & Values \\
\hline Dead load & Self weight \\
\hline Dead load at floor finish & $1.86 \mathrm{kN} / \mathrm{m}$ \\
\hline live load at floor level & $10 \mathrm{kN} / \mathrm{m}$ \\
\hline Live load at roof & $1.5 \mathrm{kN} / \mathrm{m}$ \\
\hline Earthquake load & \\
Zone & III \\
Soil type & Medium \\
\hline
\end{tabular}

The frames used for the study as mentioned earlier was designed using Indian standards IS 1893-2002(Part-1), IS 4562000 and IS 13920-1993. The frames were designed for the following load combination according to 1893-2002(Part$1)$ :

1. 1.5(DL+IL) 2. 1.2(DL+IL+EL)

3. 1.2(DL+IL-EL) 4. 1.5(DL+EL)

5. 1.5(DL-EL) 6. 0.9DL+1.5EL

7. 0.9DL-1.5EL.

\subsection{Structural Elements}

In this study, all beams and columns were modeled as frame elements. The beam and column joints were modeled by giving end-offsets to the frame elements and assumed to be rigid. For slabs due to their in-plane stiffness, "diaphragm" action at each floor level was assigned. The load contribution of slab is modeled separately on the supporting beams and the loads were uniformly distributed The foundation was considered as fixed for all the models. All the frame elements are modeled with non linear properties at the possible yield locations.

\subsection{Modeling of Hinges}

Hinges are failure points occurs when the plasticity is assumed at critical locations during the inelastic failure of the structure. There are two approaches for specifying the hinge properties:

- $\quad$ Distributed plasticity model

- $\quad$ Lumped plasticity model

In the distributed plasticity model, the zone of yielding is assumed to be spread over a certain length whereas in the lumped plasticity model, the zone of yielding is assumed to 
be concentrated at critical points in the element. The modelling approach used in this study is based on the lumped plasticity model, as implemented in SAP2000. This approach is favoured in FEMA356, which directly refers to plastic hinge rotations rather than local strains or curvatures. Plastification of the section is assumed to occur suddenly and not gradually.. There are three types of hinges namely moment hinges, axial hinges and shear hinges.

The flexural hinges in beams are modelled with uncoupled moment (M3) hinges whereas for column elements the flexural hinges are modelled with coupled P-M2-M3 properties that include the interaction of axial force and biaxial bending moments at the hinge location. Each plastic hinge is modelled as a discrete point hinge. Therefore, the plastic hinge length is considered while generating the hinge characteristics. Plastic hinge length (considering the ultimate flexural strength developing at the support) is the distance from the support over which the applied moment exceeds the yield moment. The established practice has been to take $l p=$ $0.5 \mathrm{D}$.

Typical values of roof drifts for the three performance levels are given below in table 4 (FEMA 356):

Table 4 Performance Drift values

\begin{tabular}{|l|l|}
\hline PERFORMANCE LEVEL & DRIFT VALUES \\
\hline Immediate Occupancy(IO) & $1 \%$ \\
\hline Life Safety(LS) & $2 \%$ \\
\hline Collapse Prevention(CP) & $4 \%$ \\
\hline
\end{tabular}

In this study, we consider Life Safety factor drift value. Below figure 1 shows SAP model of four storey showing hinges.

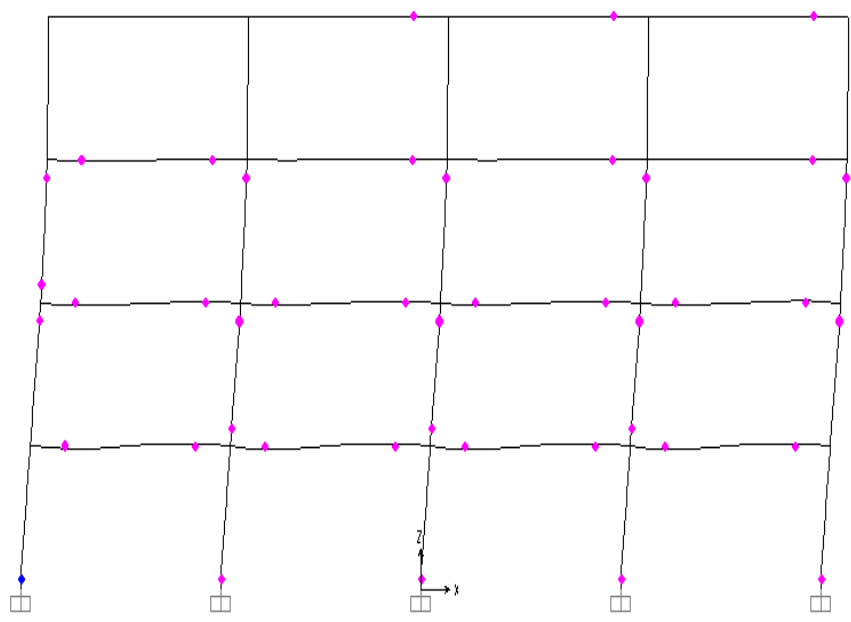

Fig 1 Hinges formation in four storey

\subsection{Nonlinear Time History Analysis}

Non-Linear Time history analysis is a step by step analysis of dynamic response of a structure subjected to a specified ground motion. Hilber-Hughes-Taylor alpha (HHT) method was used for performing direct integration time history analysis. The HHT method uses a single parameter (alpha) whose value is bounded by 0 and $-1 / 3$. These coefficients were computed by specifying equivalent fractions of critical modal damping at two different periods. The dynamic input has been given as a ground acceleration time-history which was applied uniformly at all points of the base of the structure and only one horizontal component of ground motion has been considered.

\subsection{Details of Ground Motion}

Scaling of natural ground motions was done consistent with general design spectrum given in Indian Standard IS 1893 (2002) for corresponding zone and damping ratio of five percent for each of frames. The ground motions are downloaded from a Ground motion Database in the website of Center for Engineering Strong Motion Data, USA. (http://www.strongmotioncenter.org). The frames were subjected to twice the design based earthquake thus, ground motions with PGA greater than for what it was designed was downloaded and used in the study. Maximum of ten natural ground motion was used to generate the time history analysis. The set of ground motions kept same for frames with different height. Both fault normal and fault parallel conditions are considered for each ground motions. The ground motions with PGA $0.32 \mathrm{~g}$ were used to analyze the frame and below table 5 shows the ground motion value with PGA $0.32 \mathrm{~g}$ taken from the website

Table 5 Ground motion value with PGA 0.32

\begin{tabular}{|l|l|l|l|l|}
\hline No & Earthquake & Year & Magnitude & Scale \\
\hline 1 & $\begin{array}{l}\text { Superstition } \\
\text { Hills02 Brawley } \\
\text { airport }\end{array}$ & 1987 & 6.54 & 3.367 \\
\hline 2 & $\begin{array}{l}\text { Superstition } \\
\text { Hills02 POE road }\end{array}$ & 1987 & 6.54 & 1.257 \\
\hline 3 & $\begin{array}{l}\text { Loma Prieta } \\
\text { Gilroy Array \#2 }\end{array}$ & $\begin{array}{l}\text { Calexico Fire } \\
\text { Station }\end{array}$ & 6.93 & 1.1132 \\
\hline 5 & $\begin{array}{l}\text { Superstition } \\
\text { Hills02 } \\
\text { Kornbloom road }\end{array}$ & 1987 & 6.54 & 1.9337 \\
\hline 6 & $\begin{array}{l}\text { Imperial Valley 06 } \\
\text { Compuertas }\end{array}$ & 1979 & 6.53 & 3.53 \\
\hline 7 & Kobe shin Osaka & 1995 & 6.9 & 1.5544 \\
\hline
\end{tabular}

\subsection{Design Displacement Profile}

The displacement approach procedures as follows. For regular frames, the design displacement profile is given by

$$
\Delta_{\mathrm{i}}=\omega_{\theta} \cdot \theta c \cdot H_{\mathrm{i}}\left[\left(4 H n-H_{\mathrm{i}}\right) /\left(4 H n-H_{1}\right)\right]
$$

where

$\omega_{\theta}=1$ is a reduction factor 
$\theta c=$ Drift limit $[$ FEMA 356(2002)]

$H n=$ roof height

$H_{\mathrm{i}}=$ height of $\mathrm{i}^{\text {th }}$ storey

Design $\operatorname{drift}(\Delta d)$ is given by

$$
\Delta d=\left\{\left[\Sigma\left(m_{\mathrm{i}} \Delta_{\mathrm{i}}^{2}\right)\right] /\left[\Sigma\left(m_{\mathrm{i}} \Delta_{\mathrm{i}}\right)\right]\right\}
$$

$m_{\mathrm{i}}=$ mass of $\mathrm{i}^{\text {th }}$ storey

For RC frames, yield $\operatorname{drift}(\theta y)$ is given by

$$
\theta y=0.5 \varepsilon y(L d / H b)
$$

where

$\varepsilon y=$ yield strain

$L_{d}=$ beam bay length

$H_{b}=$ beam depth

Yield displacement

$$
\Delta y=\theta y . H e
$$

where $H e=\left[\Sigma\left(m_{\mathrm{i}} \Delta_{\mathrm{i}} H_{\mathrm{i}}\right)\right] /\left[\Sigma\left(m_{\mathrm{i}} \Delta_{\mathrm{i}}\right)\right]$

$\operatorname{Design} \operatorname{Ductility}(\mu)$ is given by

$$
\mu=(\Delta d / \Delta y)
$$

Base shear is given by

$$
F=K e . \Delta d
$$

where $K e=\left(4 \pi^{2} m e\right) / T e^{2}$

$T e=$ time period calculated from response spectra chart.

\section{ANALYTICAL RESULTS}

The brief explanation about the design of selected frames on two design approaches were done and results are validated with that of time history analysis. The results of four, eight $\&$ twelve storey bare frames for the design parameters was presented below.

\subsection{Interstorey Drift}

The results of the nonlinear time history analysis was compared in terms of the inter storey drift which is the maximum drift of the structure. Inter storey drift is defined as the difference in the displacement values of adjacent storey divided by the storey height. Inter storey drift is calculated from the time history by finding the drift for each time for each storey and then the absolute maximum value is taken as the inter storey drift of that particular storey.

$$
\text { interstorey } \operatorname{drift}(\mathrm{d})=\left(\left(\partial_{\mathrm{n}+1}-\partial_{\mathrm{n}}\right) /(\mathrm{h})\right)
$$

$\partial_{\mathrm{n}+1}=$ displacement at $\mathrm{n}+1$ storey

$\partial_{\mathrm{n}}=$ displacement at $\mathrm{n}$ storey

$\mathrm{h}=$ storey height.

Drift is an important parameter used in both design approaches. The Inter storey drift parameter is considered in comparing the results which explains the non-structural damage of the structure as FBD is a strength based design approach and base shear is the fundamental parameter for the design of structures. the structural damage of a building cannot be evaluated using the above parameter alone. Hence we consider drift as a parameter. Damage is directly related to deformation and DDBD considers damage control limit state as that this limit state can be defined by strain and drift limits.

The four, eight and twelve stories frames was modeled as per procedure and non linear time history analysis was done for the structure and the drift values are predicted. Plots have been drawn showing inter storey drift of the time history analysis for all the ground motions and geomean(GM) of the same taking drift values in $\mathrm{X}$ axis while storey height in $\mathrm{Y}$ axis. Interstorey drift values for four, eight and twelve stories are shown below in chart 3 , chart 4 and chart 5 respectively.

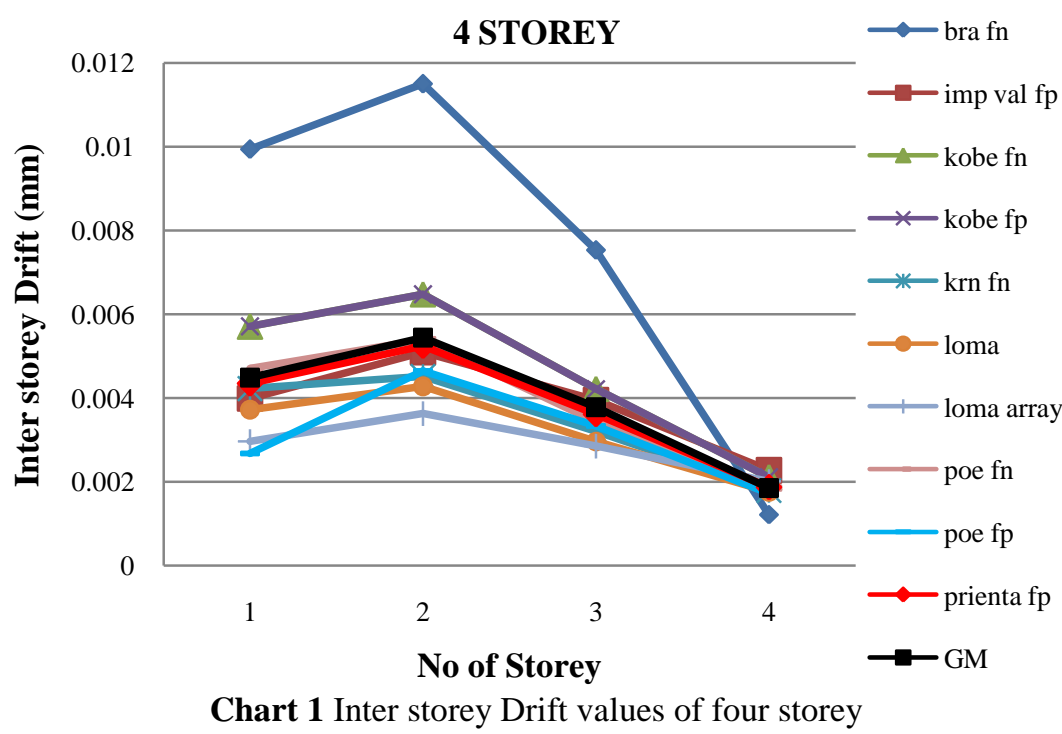




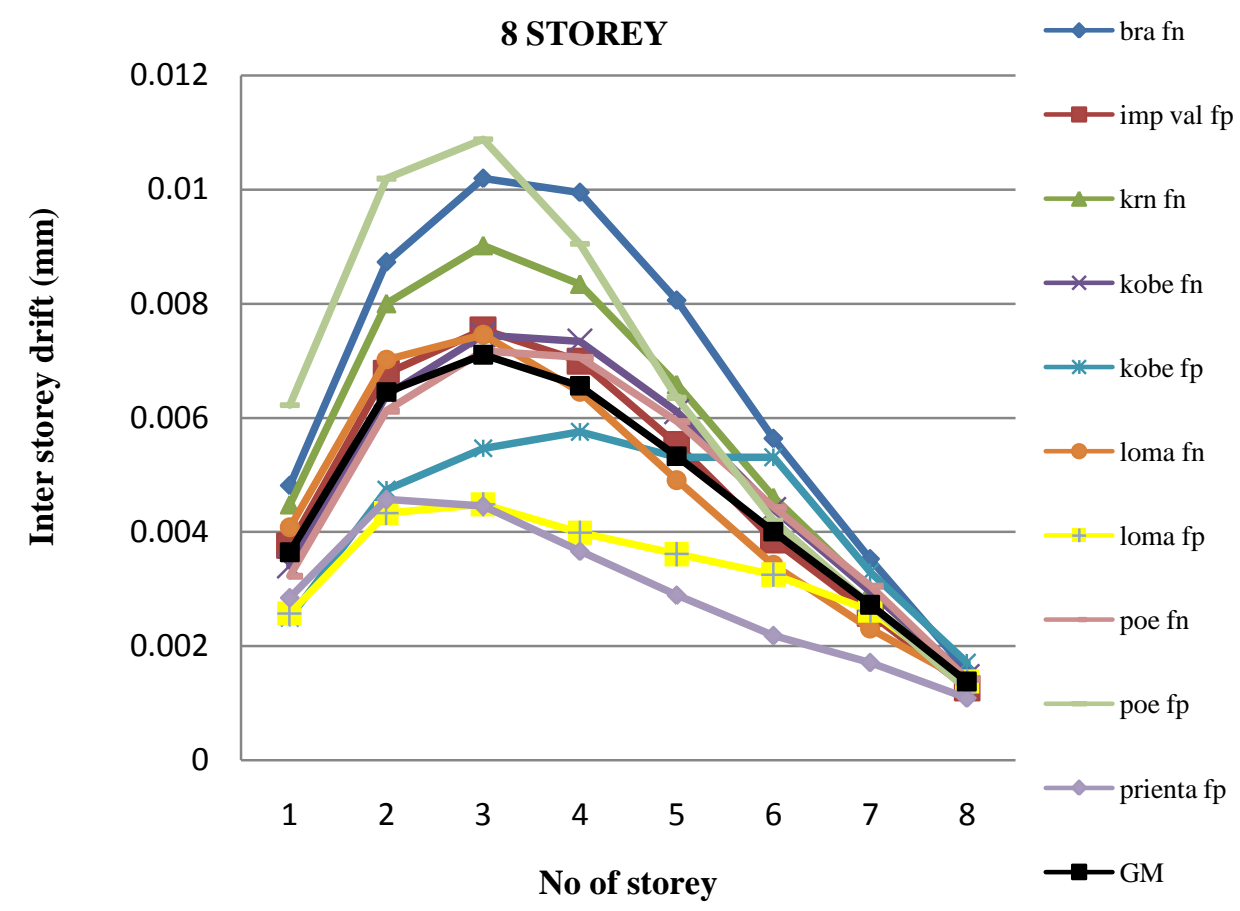

Chart 2 Inter storey Drift values of eight storey

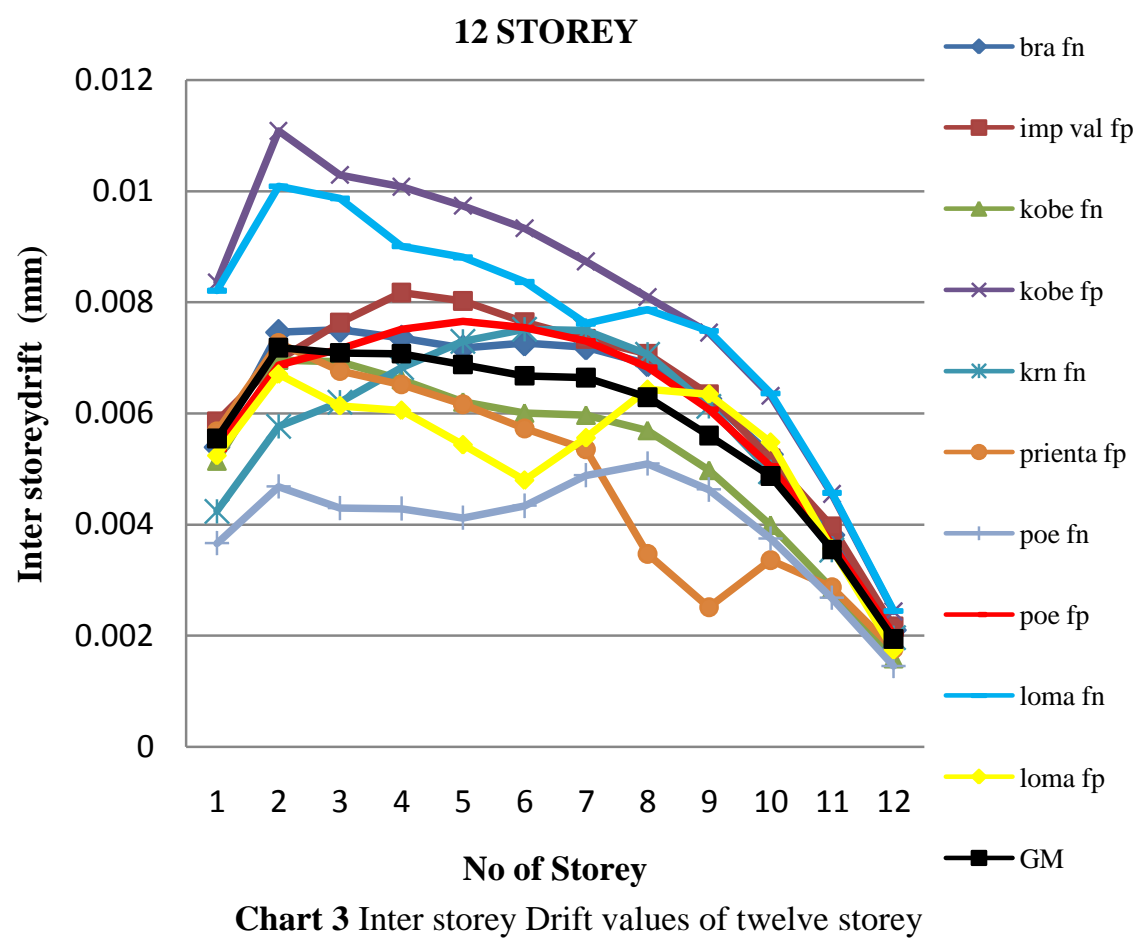

The above chart 1 , chart 2 and chart 3 explains that drift values gets increased on second storey for four storey structure and third storey for eight and twelve stories, and then gets decreased as the storey height increases, thus the maximum drift occurs at the bottom of the storey. The drift value gets decreased as the storey height increased due to shear deflection of the structure. The below table 5 shows comparison of drift values between FBD and DDBD
Table 5 Comparison of Drift values

\begin{tabular}{|l|l|l|}
\hline No of Storey & FBD $(\mathbf{m})$ & DDBD $(\mathbf{m})$ \\
\hline 4 & 0.0055 & 0.0183 \\
\hline 8 & 0.0068 & 0.0176 \\
\hline 12 & 0.0072 & 0.0158 \\
\hline
\end{tabular}

From the above table 5 the drift values for FBD is lesser than that of the DDBD comparing on their respective storey. this shows that the decrease in the displacement signifies that the 
structure is more rigid and as their flexibility is less makes the structure to collapse easily. Incase of structure with DDBD, shows high drift values makes the structures flexibility high and these values are achieved nearer to its maximum drift.

\subsection{Base Shear}

Base shear is an estimate of the maximum expected lateral force that will occur due to seismic ground motion at the base of a structure. The base shear of R.C frame buildings designed with Direct Displacement-Based Design has been compared with those designed with Forced-Based Design method.

Drift-Damage relationship alone could not define structures performances, base shear an essential design parameter which covers over the strength required for the structures at the base as the strength factor depends on the drift code limit to determine its performance level.

The below table 6 shows the base shear values of two design approaches for four, eight and twelve stories. The base shear values of DDBD structures are less compared to FBD structures, this explains that the displacement approach is preferred which results in lower stiffness and attraction of lower floor accelerations than FBD. As the Displacement approach design required base shear is directly proportional to the square of seismic intensity whereas the force based design relates linearly to seismic intensity, so displacement approach base shear values are preferred to that of the force based design approach values.

Table 6 Base shear values

\begin{tabular}{|l|l|l|}
\hline No of Storey & FBD $(\mathbf{k N})$ & DDBD $(\mathbf{k N})$ \\
\hline 4 & 237 & 207 \\
\hline 8 & 528 & 489 \\
\hline 12 & 727 & 685 \\
\hline
\end{tabular}

\subsection{Ductility Demand}

Ductility is the capacity to undergo large inelastic deformations without significant loss of strength. Reduce in ductility value results in better strength. Ductility demand is calculated from the time history by finding the displacement for each time for each storey and then the absolute maximum value is taken as the ductility in ratio with the yield displacement of that particular storey.

$$
\text { ductility demand }=(\Delta \mathrm{m}) /(\Delta \mathrm{y})
$$

$\Delta \mathrm{m}=$ maximum displacement

$\Delta \mathrm{y}=$ yield displacement

The fact that ductility of the structure has major contribution to response reduction factor for the structure which highlights the structural ductility in the seismic analysis process as depending on the level of elasticity the base condition of structure can be obtained. Drift calculated within adjacent stories alone cannot be validated for seismic design, also the relationship between all stories displacement must be taken in account as the performance check have to be done for whole structure. Hence, checking the margin displacement of each stories is a necessary one, as ductility demand is chosen as one of the design parameter.

The below graphs explain that the ductility value gets decreased as the storey height increases as the rigidity will be more at the lower storey. Increase in ductility reduces acceleration demand. Plots have been drawn showing ductility demand of the time history analysis for all the ground motions and geomean $(\mathrm{GM})$ of the same taking ductility values in $\mathrm{Y}$ axis while number of storey in $\mathrm{X}$ axis. Ductility demand values for four, eight and twelve stories are shown below in chart 6 , chart 7 and chart 8 respectively.

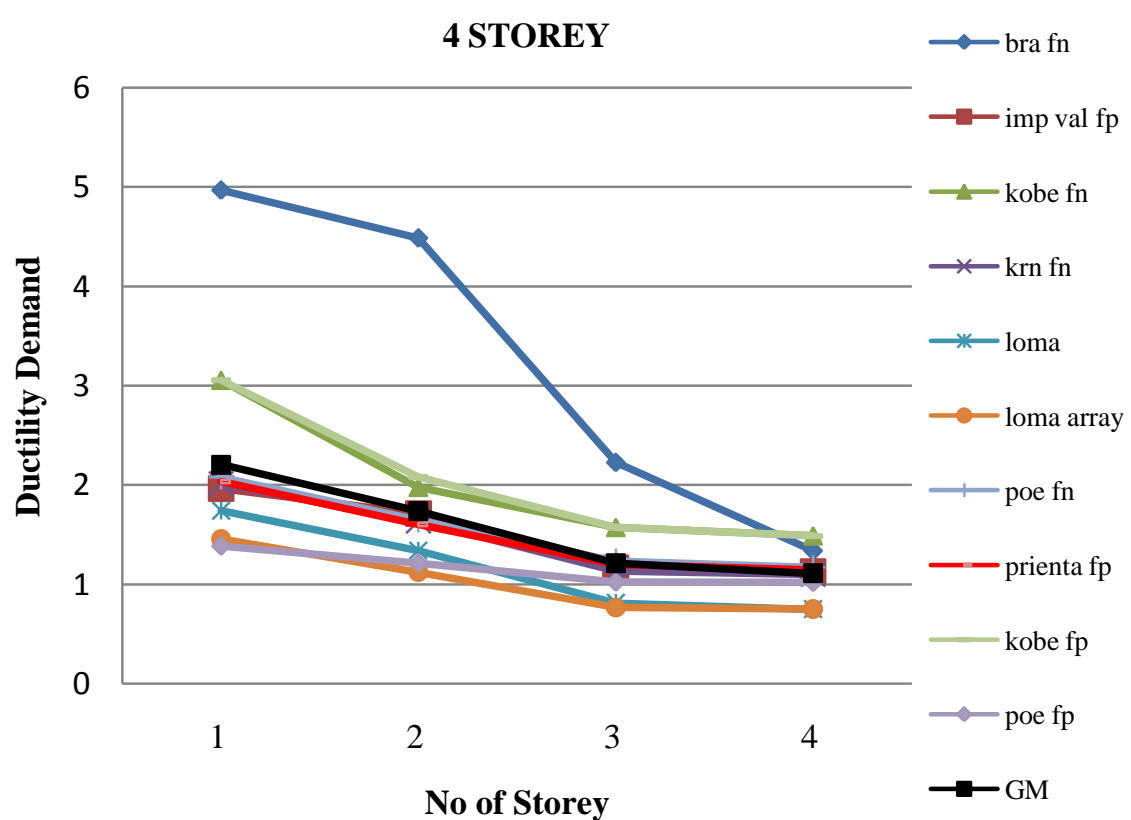

Chart 4 Ductility demand values of four storey 


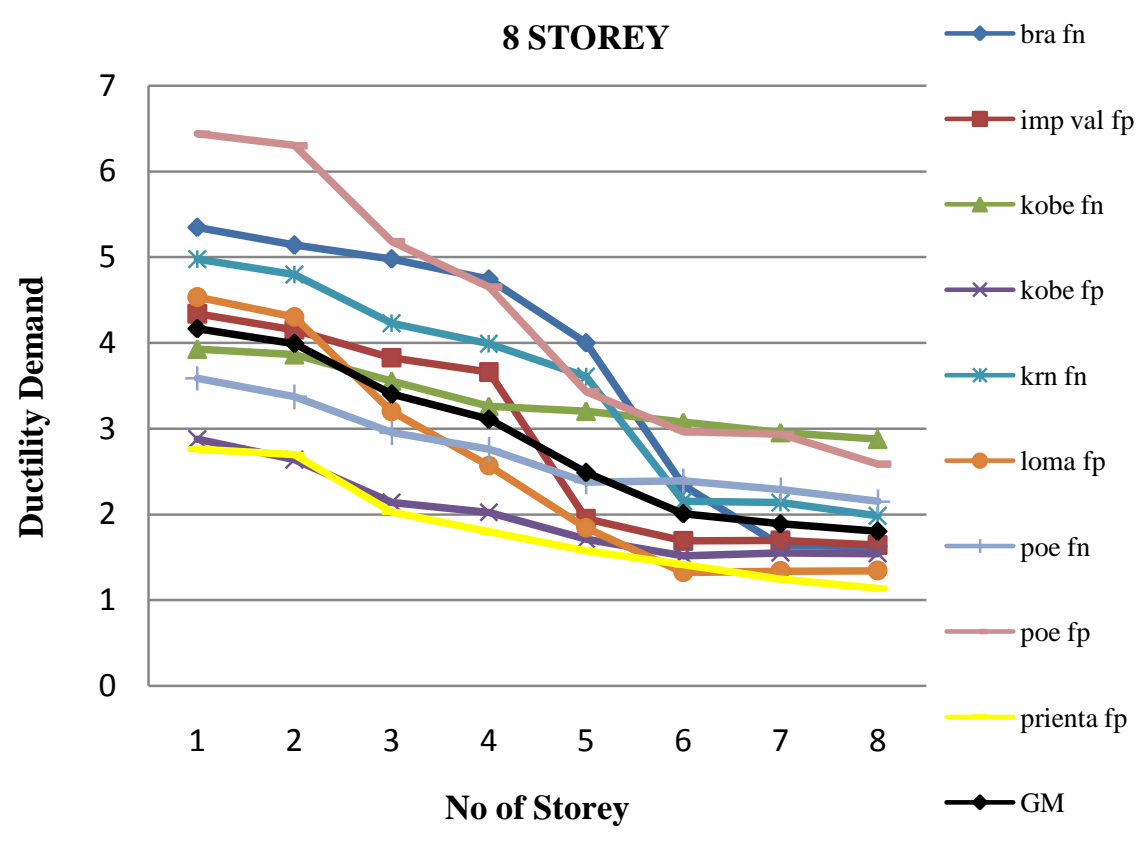

Chart 5 Ductility demand values of eight storey

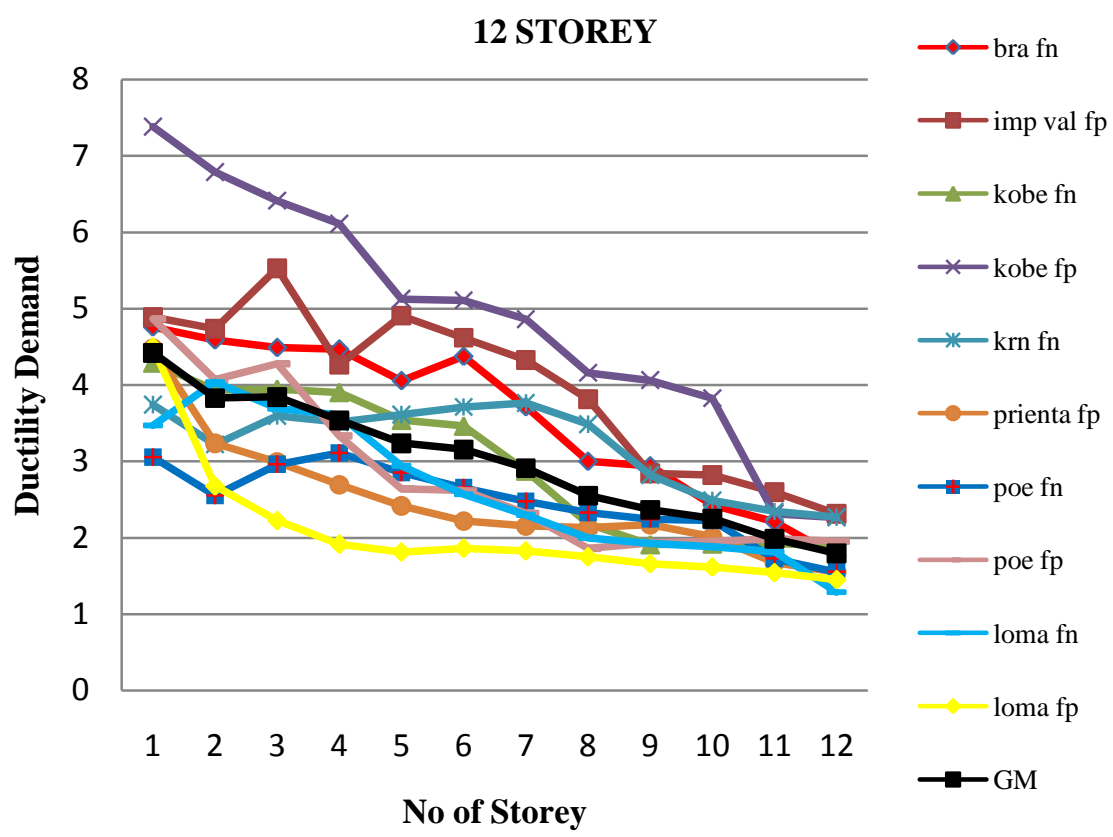

Chart 6 Ductility demand values of twelve storey

From the above chart 4 , chart 5 and chart 6 , lower stories have more displacement value then the higher stories, the ductility value gets decreased while the story height increases as the drift will be maximum at the bottom stories.

Table 7 Ductility Demand values

\begin{tabular}{|l|l|l|}
\hline No of Storey & FBD & DDBD \\
\hline 4 & 2.2 & 1.5 \\
\hline 8 & 4.19 & 1.33 \\
\hline 12 & 4.42 & 1.17 \\
\hline
\end{tabular}

From the above table 7 DDBD structure shows lesser ductility demand comparing to that of the FBD structures, this explains ductility will be maximum for DDBD structures as it undergoes deflection easily and flexibility will be high.

\section{CONCLUSION}

The above contents explains the FBD and DDBD seismic approaches performed on four, eight and twelve stories for different structural parameters and the design approaches were performed with nonlinear time history analysis and the results are validated, it concludes as. 
- Inter storey drift values of DDBD structure increases by $70 \%, 61 \%, 54 \%$ for four storey, eight storey and twelve storey respectively than that of the FBD structure.

- Maximum Inter storey drift occurs at bottom of the framed structure as the base will be more rigid .FBD and DDBD shows the drift values less than the actual design drift limit $(\mathrm{d}=0.02)$.

- Base shear values of DDBD structure decreases by $13 \%, 7.3 \%, 6 \%$ for four storey, eight storey and twelve storey respectively than that of the FBD structure.

- Force Based Design shows higher value of Base shear than Direct Displacement Based Design. As reduction in base shear values represents DDBD structure has less acceleration demands.

- Ductility demand values of DDBD structure decreases by $31 \%, 68 \%, 73 \%$ for four storey, eight storey and twelve storey respectively than that of the FBD structure.

- Direct Displacement Based Design shows lesser ductility value than the Force Based Design as DDBD undergoes flexible deflection.

Thus, overall DDBD structure shows good performance over the structural parameters and achieved design was better and safe compared to FBD structures.

\section{REFERENCES}

[1]. IS 1893(Part1) - 2002, 'Indian Standard Code of Practice for Criteria for Earthquake Resistant Design of Structures', Bureau of Indian Standard, (New Delhi)

[2]. Alefiya T. Dohadwala1, Rutvik K. Sheth2, Dr. Indrajit N. Patel3,'Comparison of Base Shear for Forced-Based Design Method and Direct Displacement-Based Design Method', International Journal of Advance Engineer ing and Research Development (IJAERD) Volume 1,Issue 6,June 2014, PP 1-9.

[3]. Helmut Krawinkler, Peter Fajfar, 'Performance Based Seismic Design concepts and implementation', Pacific Earthquake Engineering Research Center, College of Engineering,University of California, Berkeley,2004.

[4]. B.J. Davidson and R.C. Fenwick, H.J. Judi,' Displacement Focused Seismic Design Methods - A Comparative study', Pacific conference on Earthquake Engineering, feb 2003, PP 1-8.

[5]. M.S. Medhekar, D.J.L. Kennedy, 'Displacement-based seismic design of buildings - theory', 'Department of Civil and Environmental Engineering, The University of Alberta, Edmonton, Alta., Canada T6G 2G7, 2000, PP 201-209.

[6]. Aidcer L. Vidot-Vega, Mervyn J. Kowalsky, 'Drift, strain limits and ductility demands for RC moment frames designed with displacement-based and force-based design methods', Department of Civil, Construction, and Environmental Engineering, North Carolina State University, Raleigh, NC, United States, 2013, PP 128-140.

[7]. FEMA 356, Federal Emergency Management Agency Washington, November 2000.
[8]. M.J.N. Priestley,G.M. Calvi,M.J. Kowisky, 'Displacement-Based Seismic Design of Structures', IUSS PRESS, Pavia, ITALY.

[9]. Qiang Xue, Cheng-Chung Chen, 'Performance-based seismic design of structures: a direct displacement based approach', Sinotech Engineering Consultants Inc., 171 Nanking East Road Sec. 5, Taipei 105, Taiwan, march 2003 PP 1803-1813

[10]. M J N Priestly,'Performance Based Seismic Design',12WCEE,pp283,2000

\section{BIOGRAPHIES}

Vivinkumar.R.V, PG student, Department of Civil Engg, SRM university, Kancheepuram, Tamilnadu

Karthiga.S, Assistant Professor, Department of Civil Engg, SRM university, Kancheepuram, Tamilnadu 